\title{
Of narratives and nostalgia
}

\author{
Norman Duncan ${ }^{1}$ \\ University of Pretoria
}

Garth Stevens

University of the Witwatersrand

Christopher Sonn

Victoria University and University of the Witwatersrand

Running head: Of narratives and nostalgia

\begin{abstract}
This article provides an introduction to and outlines the rationale for the focus of this special issue, Of Narratives and Nostalgia. It therefore provides a broad description of the Apartheid Archive Project, which had served as the platform for the development of all the articles contained in this special issue. Additionally, it sketches the broad contours of, and interrogates, some of the key theoretical constructs that recur across the articles constituting this special issue. These include the constructs, nostalgia, mourning, pathological grief, melancholia, and racial melancholia. Importantly, the article very briefly also explores the some of the potentially socially disruptive sequelae as well as the arguably creative and generative functions of nostalgia in personal narratives of the past. The article concludes with evaluative summaries of all the articles contained in this special issue.
\end{abstract}

\section{Introduction}

The last three decades have seen a significant resurgence in the use of the concept of nostalgia in the social sciences and humanities, not as Johannes Hofer initially described it in 1668 (Sedikides, Wildschut \& Baden, 2004), but as a critical analytic category through which to understand a range of contemporary cultural, social and psychological phenomena. Svetlana Boym's (2001) influential The future of Nostalgia, and the emergence of the concept of ostalgie to explain the 'desire to return' in parts of the former Eastern Bloc countries (Cooke, 2005), are two

\footnotetext{
1 The author to whom all correspondence should be addressed at norman.duncan@up.ac.za
} 
illustrations of its contemporary purchase power. Most researchers, practitioners and academics today, who have engaged in work on memory, subjectivity, the postcolonial condition and societies in transition, amongst others, are familiar with this analytic lens. Indeed, many of the authors and editors in this special issue, who work in and write on South Africa's conflictual past and challenging present, have also been acutely aware of this resurgence. In particular, nostalgia has found its way into the scholarly expositions of many within South African academy (see for example, Mbembe, 2008) as well as contemporary South African literature (see for example, Dlamini, 2009). Allusions to the 'good old days', can frequently also be discerned in the everyday accounts and meaning-making strategies of South African citizens, as illustrated in many of the narratives collected from within the Apartheid Archive Project (see www.apartheidarchive.org). It is indeed the identification of this phenomenon in the Apartheid Archive Project narratives that ultimately provided the impetus of this special issue.

By way of further introducing this special issue, some background to the Apartheid Archive Project would perhaps assist in framing the articles presented herein.

The Apartheid Archive Project is an international research initiative that aims to examine the nature of the experiences of racism of 'ordinary' South Africans under the old apartheid order, and their continuing effects on individual and group functioning in contemporary South Africa. The project is fundamentally premised on the understanding that historical and collective experiences of trauma will constantly attempt to re-inscribe themselves in the present if they are not acknowledged, interrogated and addressed (see Hamber, in this issue, for a critical interrogation of this understanding). While processes such as the Truth and Reconciliation Commission have arguably made a critical contribution to this process, its tendency to focus on the more dramatic or salient narratives of Apartheid atrocities foreclosed the possibility of an exploration of the more quotidian manifestations of Apartheid abuse. It is largely for this reason that the Apartheid Archive Project attempts to foreground narratives of the everyday experiences of 'ordinary' South Africans during the Apartheid era, rather than simply focusing on the 'grand' narratives of the past or the privileged narratives of academic, political and social elites. To this end, 
the project endeavors to collect, document, analyze and provide access to personal or narrative accounts of the impact of apartheid on the lived realities of their authors. Initiated in 2008 by 22 core researchers located at universities spanning South Africa, Australia, the United States and United Kingdom, this collective began exploring whether the concept of nostalgia as a critical category of analysis could extend our current understandings of the particular and ongoing manifestations of racialization processes in South Africa's present. In addition, the collective posed itself the question: if an augmented analysis could emerge from an engagement with and a deployment of this analytic lens, then what are the boundaries thereof and what are its consequent limitations? This ultimately led to the Third Apartheid Archive Conference on Narratives, Nostalgia and Nationhoods in 2011, from which many of the articles within this special issue have been drawn. While this issue is devoted to nostalgia within a South African context, this should not be viewed as a claim to exceptionalism related to this context. On the contrary, we believe that an analysis of the concept of nostalgia may be beneficial to other post-authoritarian, transitional social contexts as they manage conflict and engage in peace-making, building and -promotion strategies. This analysis would obviously also be of value in many contemporary social contexts that are characterized by rapidly increasing levels of social dislocation and subjective and relational dynamism and flux, frequently resulting from rapidly changing geo-political conditions and increasing global economic instability.

\section{A word on nostalgia}

First introduced into the literature in 1668 by the Swiss physician, Johannes Hofer, nostalgia was originally conceptualized as a neurological condition characterized, inter alia, by desperate sadness, suicidal tendencies and psychic pain associated with a intense longing for home (Sedikides, Wildschut \& Baden, 2004). Hofer first identified the condition amongst Swiss mercenaries involved in a number of wars on behalf of various European rulers (Smith, 2000). While Hofer essentially introduced the concept into the nomenclature and psychiatric nosology of the time, it was of course premised on the earlier term, Heimweh (homesickness) (see Laubscher, this issue; Brock \& Truscott, this issue). 
Towards the end of the nineteenth century nostalgia, was increasingly typified as a form of melancholia, with anxiety and sadness, insomnia and loss of appetite constituting its primary symptoms. This conceptualization was carried into the twentieth century, largely by proponents of the psychoanalytical tradition (Sedikides et al., 2008). Of course, many writers today, as indicated by Brock and Truscott (this issue), would argue that melancholia and nostalgia are two distinct constructs.

Naqvi (2007) has also provided a historical account of the evolution and utilization of the concept, highlighting how it was deployed with reference not only to soldiers who were seemingly unpatriotic, but also to criminals, the peasantry, and indigenous black populations in the era of colonialism. In many of these instances, the term was often used to describe, marginalize and contain socially and politically subversive or 'deviant' groups.

More recently, nostalgia has also been conceptualized as a fundamentally social process that reinforces social connections and connectedness (Davis, in Sedikides, Wildschut, Arndt \& Routledge, 2008). While the individual invariably is the chief protagonist in personal nostalgic narratives, she or he is located in the narratives as part of a social environment. Importantly, within personal nostalgic narratives or reveries, the individual is invariably connected to other social agents (Sedikides, Wildschut, Gaertner, Routledge \& Arndt, 2008). Nostalgia is also social in the sense that its constituent elements invariably borrow from circulating and referent discourses (for example, the ubiquitous discursive elements involving rampant crime and corruption circulating in contemporary South Africa are frequently accompanied by implicit evocations of an idyllic past that was free of these social ills).

A further development in this area refers to the relationship between nostalgia, temporality and place. Kant (in Hutcheon, 1998) remarks that people often do not want to return to a place or space in the past, but "to a time; a time of their youth" (p. 3). However, as Hutcheon (1998) observes, unlike space, an earlier time cannot ever be returned to. "Time is irreversible. And nostalgia becomes a reaction to that sad fact" (Hutcheon, 1998, p. 3). Nostalgia, Hutcheon observes, is a reaction to an irrevocably lost past and it is this that imbues it with such power. 
Of course, the negative attributions invariably associated with nostalgia as a regressive response has been challenged by Boym's (2001) distinction between reflective and restorative nostalgia. In the first instance, reflective nostalgia allows for a way of engaging with a past that critically challenges official histories and 'grand' narratives, while restorative nostalgia refers to the desire for return to and reinstatement of a past.

While the developments above signal the ongoing evolution of the concept, nostalgia has also been provocatively critiqued. Smith (2000) cautions that in our attempts to understand the history and uses of the term, it is important that we bear in mind that the term was profoundly influenced by nineteenth and twentieth century political contestations about the "significance of the past" (p. 505). Indeed, she argues that, as from the nineteenth century, various social and political elites increasingly harnessed the term to delegitimize or dismiss the stances and claims of their opponents. She argues that the term was increasingly also used as a diagnosis of disease to "manage and contain" "aberrant" social behaviors from the perspective of the dominant classes; 'aberrant' behaviors such as soldiers absconding from their commissions and household servants setting their employers' houses alight in the hope of being sent home to their families!

Naqvi (2007) similarly highlights that we need to be careful of being uncritical of nostalgia as a critical analytic category itself. He argues that the historical deployment of the concept has always taken place through the matrix of moral orthopedics and in the service of disciplinary power, when resistance to that power has emerged from marginalized minorities. He concludes that an uncritical focus on nostalgia results in an elision, concealment, and obfuscation of other power relations that are at play within societies (for example, in focusing on nostalgic subjects as objects of analysis, we may be blinded by the disciplinary power embedded within the inherently fraught process of nation-building itself).

While we are keenly aware of these critiques, the aim of this special issue is to interrogate the ways in which the expanded analytic construct of nostalgia may be able to extend our analyses of a racialized social formation like South Africa as it emerges from a history of conflict, we anticipate that the boundaries of its utility will no doubt generate new critical questions as well. 


\section{The affective turn: on nostalgia, mourning and melancholia}

Why has the concept of nostalgia been so widely appropriated across disciplinary boundaries within the social sciences and humanities today? Part of the answer may lie in the evolution of the term itself, with the term being utilized in a myriad of variegated ways as a foil, a metaphor or a symbolic representation of issues pertaining to subjectivity, memory, history, and social relations in contexts that are, or have undergone transitions.

It is worth noting the manner in which the 'affective turn' appears to have supplanted the 'linguistic and discursive turns' that were so evident in the latter half of the twentieth century in the social sciences and humanities. As a concept that is fundamentally defined in relation to affect, nostalgia appears to be readily available for incorporation into analyses that have as part of their intention, some referential discussions on affectivity. Here of course, Freud's (2005) seminal work, Mourning and Melancholia, is frequently cited (see, for example, Gobodo-Madikizela, this issue; Brock \& Truscott, this issue), and perhaps requires some attention as a seminal text that provides a comprehensive account of the potential psychological functions of nostalgia.

\section{Mourning and melancholia}

For Freud (2005), mourning is commonly the reaction to the loss of a loved object in the external world, be that object a person, place or abstraction of sorts. While certainly resembling the depressive features that Freud later associated with melancholia, he notes that the loss of the object in reality results in a countertendency to turn away from reality and to the internal representation of the lost object. One way in which this is done is through the denial of any negative attributes of the lost object in internal fantasy - that is, the maintenance of an idealised version of the object; a pristine version of something that no longer exists. This idealisation is itself often projected onto memories, moments, experiences, places, people or times in the past. It is fundamentally an experience of loss in the present reality that results in a return to an imagined and idealised past that also reflects the preservation of an internal representation of that object. Through such an 
idealisation of the lost object, we protect the integrity of the internal representation of the real object that has been lost, but we slowly start to see the lost object in a more balanced manner over time, thereby reducing the need for us to maintain it as an idealised, imagined and fantasized artefact. For Freud (2005, p. 204), "normally, respect for reality carries the day" and we cathect into substitute objects, thereby also severing the linkage between the libido and internal representations of the lost object.

Melancholia, on the other hand, is an extension of mourning or the possibility of mourning in perpetuity. It is the persistent feeling that whatever is lost in reality is also deeply embedded in the self (for example, loved ones or identities). But, it is also premised on the idea that we have highly ambivalent relationships to such internalised objects within the self. Suchet (2007, p. 873, citing Freud, 1923) notes:

[Freud] later referred to the structuring role of melancholia whereby the individual takes the lost object into the ego as a way to circumvent giving up the object. In other words, the melancholic preserves the lost object in the form of an identification. (p. 873)

In this way, object-cathexis is replaced by identification as the introject replaces the loved object that has been lost in reality (Jacobs, 2003). There is thus the constant navigation between having it and not having it, of loving it and hating it simultaneously. In losing that which we experience in reality (for example, a loved one; or whiteness, for that matter) that is also part of ourselves, the libido feeds on the ego itself to satisfy its cathectic needs, resulting in the ego often feeling incomplete, empty depleted and deficient in some way or another. Melancholia is thus a loss that is experienced internally, rather than externally, often leaving one with sense of feeling 'bad'. This distinguishing feature of melancholia is what Freud (2005) refers to as "the disorder of self-esteem" (p. 204).

\section{The social manifestations of nostalgia in South Africa: three possible deployments}

So what is the relationship between these psychological states and nostalgia as a social phenomenon in South Africa? How can a critical analysis of nostalgia as a 
construct provide us with a lens (see Radstone, 2010) into memory, narrative, history and their relationships to both the past and the present?

\section{Reflective nostalgia as 'mourning'}

Dlamini (2009), in his Native Nostalgia, speaks to Boym's (2001) idea of a reflective nostalgia in which there are attempts to reflect on memory fragments that help to destabilise negative, taken-for-granted assumptions about life during apartheid as a black person. We see many similar kinds of nostalgic deployments in narratives that reify 'heroic', anti-apartheid struggles; that romanticise to some extent the locations and ghettos of apartheid South Africa, and that counter the tendency to think of the past as a damaging set of insults that are directed at oppressed peoples. Instead, this form of nostalgia may offer up some elements of resistance and reclamation; opposed to the emasculation, denigration, dehumanisation and inevitable characterisation of blacks as damaged. This type of nostalgia perhaps emerges at moments of flux in a social system that may in turn generate personal moments of crisis - where the ideals of a better future have somehow not come to fruition in contemporary South Africa, and have thus been lost and mourned. For some, this form of nostalgia is perhaps a mourning that reflects contemporary South Africa as a place of disappointment rather than one of actualisation, and the past is reified in relation to the disillusioned present (See Moiloa, in this issue, for an interesting exposition of this variant of nostalgia).

\section{Nostalgia as 'racial melancholia'}

Nostalgia may also not only be deployed in the manner mentioned above, but in social systems that are premised on fundamental double-binds or ambivalences, social identities may themselves be internalised in ambivalent ways (for example, both blackness and whiteness are now no longer fixed, but are fluid in postapartheid South Africa). Given that these social identities are 'objects' in reality that are also then internalised, we may experience persistent loss and ambivalence in relation to the absence of fixity in these identities in some way or another in contexts of social transition (specifically, after a prolonged exposure to such ambivalences, we feel in-between, not located, no sense of coherence). Suchet 
(2007), drawing on Eng and Han's (2000) work on racial melancholia, examines Straker's (2004) focus on the melancholia experienced by white South Africans. She notes that:

The paths to melancholia are multiple including the recognition of one's limited access to whiteness as real power and the loss of the ideal of whiteness as expressed in its humanitarian values of equality and justice (Eng \& Han, 2000). It is a third route added by Straker that particularly interests me-racial melancholia initiated through the recognition that one is the involuntary beneficiary of whiteness. Not only is the ideal of whiteness betrayed, but one benefits from precisely that which contradicts one's fundamental values. The melancholia of the beneficiary ... is the experience of loss, a diminishment in the sense of self as we see through whiteness. It is the recognition that under the mantle of whiteness there is the perpetration of violence, terror, and the infliction of psychological damage. It is with horror that we come to own the destructiveness that is a part of whiteness. The rewards and benefits given to whites automatically implicates us in the acts performed to attain those privileges. There is a realization of our complicity as the beneficiaries of whiteness. We benefit despite ourselves, despite our beliefs, values, and ideals. (p. 874)

While Freud's initial conceptualisation of melancholia suggested that a preservation of the lost object in reality through an internalisation and identification with that object was more extreme than the normal mourning process, Suchet (2007) raises the question as to whether this is necessarily negative in its consequences. She suggests that inherent ambivalence in the melancholic position opens up the possibility for redefining a new coherence that is premised precisely on fragmentation, incoherence and transformation. In other words, racial melancholia opens up possibilities for more complex identity formations, if worked through appropriately. 
Reflecting on the Alternative Afrikaner Rock Movement in South Africa in the final days of apartheid, the recent work by the Afrikaans singer, Koos Kombuis (2009), titled Short Drive to Freedom provides an poignant description of racial melancholia and whiteness at play. Kombuis stirringly notes how he comes to a realization about his complicity as a white South African, and how his fanciful ideas about being a voice of resistance are shattered when he reflects on his rather colorful forms of resistance that revolved around drug-taking. Truscott (2010) notes that when Kombuis's wife asks him what this period of his life meant to him, he claims that it "damaged" him. It is the shattering of an ideal as well as coming to terms with both the loved and hated parts of the self as a white person that arguably causes Kombuis to offer his particular response. However, what it raises, which Suchet (2007) speaks of, is the possibility of reconfiguring the self in potentially transformative ways.

\section{Nostalgia as 'pathological grief'}

Nostalgia may also be deployed in much more deliberate ways that draw on even more extreme versions of melancholia - perhaps those akin to the manifestations of a complicated grief reaction. Dlamini's (2009) reference to Boym's (2001) work on restorative nostalgia is also an instructive illustration here - a mechanism for attempting to re-establish a past that has been lost in the present. This is not simply a process of mourning, nor a depressive ambivalence of melancholia, but an active pursuit of that which is lost (yet simultaneously almost denying its loss). Nostalgia may be deployed through processes akin to mummifying the surroundings associated with the lost object in reality, which one sometimes encounters in pathological grief. By attempting to preserve and mummify the very circumstances in which the lost object 'lived', nostalgic reactions may very well come to represent a form of pathological grief in which the lost object is actively 'kept alive'. In these instances, it is important to note how nostalgia's deployment is almost always ideological in character, sometimes masking crises in contemporary societies and yearning for 'days gone by', but also acting as the fulcrum for political mobilisation (for example, during the rise of Fascism in the early 1900s; the rise of the Afrikaner Right in South Africa; the Ostalgie of former-East Germans, and the desire for a 
return to Stalinism and the glory days of mother Russia) (see Berdahl, 1999). Here we see the use of symbols that link us back to a past (for example, the flags and anthems of the old order), a denial and simultaneous recognition of the loss in the present, constantly searching for that idyllic lost item, but always denying its loss through a mummified version of the past that is imagined and unreal.

Either way, nostalgia seems to be a way of easing the pain of 'death' of someone or something in the present, literally or figuratively - sometimes momentary and socially affirming, as in the case of reflective nostalgia that is aimed at resistance and reclamation. Sometimes the process is prolonged and ambivalent but potentially transformative, as in the case of racial melancholia that has the potential to lead to self-reflection. And sometimes it is a deeply counter-productive disengagement with the present and an intractable return to an imagined past, as in the deliberate ideological deployment of nostalgia in a restorative manner. Nostalgia is in some sense a personal and collective process that emerges at the point where social systems are in transition or at a juncture moment of imminent and distressing disintegration (Radstone, 2010). Importantly, it fundamentally represents a loss in the reality of the present. This idealisation of that which has been lost in the present is then cast back onto the past and becomes inscribed onto another moment, time or place, resulting in perfectly preserved nostalgic moments that are of course always imagined, fantasised, unreal, partial, oblique, and perspectival. Thinking about nostalgia through such analyses perhaps takes us in directions that transcend the descriptions of falsehoods that Dames (2010) refers to, and opens up ways of thinking about the psychological and social purposes of deploying nostalgia.

\section{The content of this special issue}

This special issue brings together an interesting mix of articles providing a range of perspectives on the past, collective and personal histories, memory, nostalgia, narratives, and nationhood, as well as a range of related concepts and issues. Importantly, the implications for peace and conflict are readily apparent in the articles.

In the first article in this special issue, Laubscher examines the question: What are the nature, ends and means of nostalgia? He reviews and critiques the standard understandings of nostalgia as focused mostly on the past and as a notion 
largely about ego. He then draws on the philosophical writing of Emmanuel Levinas to offer a different movement of nostalgia, "one that is about phenomenology of subjectivity in relation, of the conjoining of totality and infinity, and with regard for alterity". As he develops his argument it is clear that nostalgia is not fixed, static, essentialist, but about multiple movements and always in relation.

Hook examines nostalgia as a defensive mechanism in the second article of this special issue. He is specifically interested in clarifying the transformative and political potential of nostalgia and argues that there needs to be an adequate consideration of the psychological and affective if this potential is to be realized. He draws on different notions from psychoanalytic theory to assess the capacity of nostalgia to be transformative. He uses notions such as screened memory and fantasy to show how nostalgia can either function as a defensive strategy or as liberatory and transformative.

Based on an analysis of a corpus of written narratives as well as narratives communicated orally in an informal context, Sonn's article sets out to examine the everyday racism experienced in South Africa by a group of ex-South Africans now living in Australia as well as the effects of the experiences of racism on the latter's subjectivities. Critically, the article also sets out to examine the functions of narrating past experiences of oppression. Multi-faceted, but simultaneously focused in scope, one of the most compelling aspects of the article is its examination (based on the data analyzed) of the under-explored notion of uncivil attention or everyday racist incivilities.

Using an analysis of an online discussion (involving a harrowing tale of Apartheid-era racism) involving a group of white South Africans as her point departure, Gobodo-Madikizela, in the fourth article in this special issue, examines the intersection of nostalgic idealization and the denial of Apartheid racism. Furthermore, she explores the utility of psychoanalytic theory in examining nostalgic idealization and denial in the functioning and transformation of racism. Employing the work of Mitscherlich and Mitscherlich (1975), Gobodo-Madikizela argues that the denial of South Africa's racist past as well as the idealization of this past reflected in the afore-mentioned online discussion (and frequently evident in broader South 
African society) reflect a 'resistance to mourning'. This, the author posits, serves as a significant obstacle to reconciliation and the transformation of South African society. Hamber's article focuses on the increasing public visibility in contemporary society of 'conflict museums', which the author defines as those "permanent sites of conservation and exhibition that focus on the legacy of political violence". Importantly too, the article examines, firstly, whether conflict museums can prevent past atrocities from being repeated; and secondly, whether the notion of nostalgia has any value within an analysis of conflict museums. After examining the work of a range of authors and taking cognizance of the complexity of violent conflict, Hamber concludes that no compelling evidence has yet been produced to support the argument that conflict museums will in and of themselves prevent the occurrence of future atrocities. In the latter part of the article, the author examines how nostalgia comes into play in memory work related to past atrocities. In this section of the article he develops the notion of regenerative nostalgia in his examination of how South Africa's apartheid past is remembered, thereby extending the typology developed by Svetlana Boym (2001) in relation to the notion of nostalgia.

Mohamed and Ratele's article explores the dynamics of memory and nostalgia in a corpus of narratives extracted from the Apartheid Archive Project database, and specifically, the impact of memory on the construction of postapartheid identity. Given the article's attention to the heretofore largely neglected issue of the effects of the Apartheid-era attacks on black parental authority on identity, the article adds significantly to the value of this special issue.

The article by Frankish and Bradbury examines the narratives of trauma recounted by a group of six mothers and grandmothers from a township in Durban, South Africa, as vehicles of secondary trauma as well as discipline. The article describes the silence maintained by these research participants about traumatic violent events (largely to protect their children, the authors argue) as well as nostalgia for the period preceding these traumatic events, even though this period too is characterized by oppression. Utilizing Eva Hoffman's (2004) notion of the hinge generation, the authors argue that even when narratives of the past are silent about the episodes of traumatic violence of that past, the generation following the one that had been subjected to certain traumatic experiences apprehend and indeed 
bear the marks of these experiences. In the second half of the article, the authors compellingly argue that the silences and nostalgia reflected in the narratives serve as both psychological defense mechanisms and mechanisms to control the behavior of young people. This protective impulse on the part of the research participants, the authors argue, has profound effects on the possibilities for the emergence of new narratives in post-apartheid South Africa.

Focusing on narratives dealing with domestic work in the Apartheid Archive Project database, Shefer, in Fraught tenderness: Narratives on domestic workers in memories of Apartheid, examines how relations of power are reflected in these narratives, and importantly how privilege had been constructed and maintained not only during the Apartheid period but also in the articulation of the narratives themselves. Critically, the article also explores how the condition of domestic workers engendered violence against the latter and how this violence may be perpetuated in the present. One of the more informative aspects of the article is its exploration of how memory may be put to use in efforts to assuage or expiate the guilt of complicity in past and current manifestations of oppression.

In their contribution to this special issue Brock and Truscott examines the differences and resemblances between nostalgia and melancholia as well the different kinds of analyses of post-transition societies they permit. The authors conduct this examination of melancholia and nostalgia primarily by means of an exploration of melancholic post-Apartheid Afrikaner self-parody and a form of Ostalgie, namely nostalgia for the former German Democratic Republic. Brock and Truscott argue that while melancholia and nostalgia share several key features, including their association with lost objects located in the past, their origins in loss of a 'narcissistic type', and the fact that both phenomena can be conceptualized as functioning as forms of psychological defense, these concepts nonetheless have distinctive relations to the past. These differing relations to the past are extensively explored in the article.

Using Hirsch's notion of postmemory as an analytical framework, Moiloa's article endeavors to explore how three young men in the South African township of Khutsong attempt to make sense of and negotiate the meaning of the realities of township life in contemporary South Africa. The article's analysis of these young 
men's deployment of memories that can only be those of previous generations, in order to understand and navigate the hardships of township life, as well as the vagaries of local politics is compelling and instructive. Also very instructive is the article's examination of postmemory as a mechanism utilized by young people to resolve the apparent dissonance between their ideological allegiances and their life choices.

In the final article of this special issue, Bradbury examines how narratives of the past may provide opportunities for future possibilities. She is particularly interested in how current identity making is informed by history and what the possibilities are for constructing alternative futures. Drawing on narrative theorizing while highlighting the idea of narrative unconscious, she argues that nostalgia may not only be about longing for the way things were but also about futures that were foreclosed. For Bradbury, the critical questions concerning nostalgia relate to longing for the future, a future place, and about creatively and proactively engaging our own nostalgia to produce future belonging.

\section{References}

Berdahl, D. (1999). "(N)Ostalgie' for the present: Memory, longing, and East German things'. Ethnos, 64(2), 192-211.

Boym, S. (2001). The future of nostalgia. New York: Basic Books.

Cooke, P. (2005). Representing East Germany since unification: From colonization to nostalgia. Oxford: Berg.

Dames, N (2010). Nostalgia and its disciplines: A response. Memory Studies, 3, 269. Retrieved from http://spmss.highwire.org/content/3/3/187.short

Dlamini, J. (2009). Native nostalgia. Auckland Park: Jacana.

Eng, D.L. \& Han, S. (2000). A dialogue on racial melancholia. Psychoanalytic Dialogues, 10, 667-700.

Freud, S. (2005). On murder, mourning and melancholia. London: Penguin.

Hoffman, E. (2004). After such knowledge: Memory, history and the legacy of the Holocaust. New York: Public Affairs.

Hutcheon, L. (1998). Irony, nostalgia, and the postmodern. University of Toronto English Library. Retrieved from http://www.library.utoronto.ca/utel/criticism /hutchinp.html.

Jacobs, M. (2003). Sigmund Freud. London: Sage.

Kombuis, K. (2009). Short drive to freedom: A personal perspective on the Afrikaans rock rebellion. Cape Town: Human \& Rousseau. 
Mbembe, A. (2008). Passages to Freedom: The politics of racial reconciliation in South Africa. Public Culture, 20(1), 5-18.

Mitscherlich, A., \& Mitscherlich, M. (1975). Inability to mourn: Principles of collective behaviour. New York, NY: Grove Press.

Naqvi, N. (2007). The nostalgic subject: A genealogy of the 'critique of nostalgia'. Retrieved from http://www.cirsdig.it/Pubblicazioni/naqvi.pdf

Radstone, S. (2010). Nostalgia: Home-comings and departures. Memory Studies, 3, 187-191. Retrieved from http://spmss.highwire.org/content/3/3/187.short

Sedikides, C. Wildschut, T., Arndt, J. \& Routledge, C. (2008). Nostalgia : Past, Present, and Future. Current Directions in Psychological Science, 17, 304.

Sedikes, C., Wildschut, T., \& Baden, D. (2004). Nostalgia: Conceptual issues and existential functions. In J. Greenberg (Ed.), Handbook of experimental existential psychology (pp. 200- 214). New York: Guilford.

Smith, K. K. (2000). "Mere nostalgia: Notes on a progressive paratheory". Rhetoric and Public Affairs, 3, 505-27

Straker, G. (2004). Race for cover: Castrated whiteness, perverse consequences. Psychoanalytic Dialogues, 14, 405-422

Suchet, M. (2007). Unraveling whiteness. Psychoanalytic Dialogues, 17, 867-886

Truscott, R. (2010). The afterlife of voëlvry in post-apartheid South Africa. Psychology in Society, 40, 108-111. 